\title{
How images are the making of the Women's Art Library/Make
}

\author{
Althea Greenan
}

W hen a group of women artists decided to organise their slides to inspire others to document themselves and raise the visibility of women's art, they could not have known that several decades later those slides would still be together, forming the core of an internationally significant research resource. How did this idea of gathering together images transform a women's art group - in the 1980s these were almost as common as book groups are today - into the Women's Art Library/Make collection? Historically rooted in gender politics and the subsequent emergence of a radicalised women's art practice and feminist art criticism, WAL/Make is an exciting 'work in progress'. Now based in Goldsmiths, University of London it is being developed as a key special collection by the Library.

\section{Building up a picture}

The Women's Art Library/Make is a London-based collection of documentation that was officially constituted as the Women Artists Slide Library in 1982. Its focus is contemporary women's art in the sense that most of the artists are still living, but not necessarily working, at the forefront of art practice. However the WAL/Make is recognised as an important vanguard organisation with a crucial responsibility to raise the visibility of women artists and create a dynamic context that challenges the critically indifferent art mainstream. It benefited from a start-up grant from the Cohen Trust in 1982, followed by funding from the Greater London Council Women's Committee and later the London Arts Board and the Arts Council of England, which supported its activities for nearly 20 years. Many project grants were secured throughout that time including awards from the Paul Hamlyn Trust, the Baring Foundation, Esmée Fairbairn Foundation, Madeline Mabey Trust, the Calouste Gulbenkian Foundation, the European Union and more.

WAL/Make's beginnings are complex but the collection itself was born of artists' desire to gather together their slides to create a resource on women's art. To ensure these images became effective conduits to the artist's studio, a membership system was set up, with a low annual fee that eventually prompted the introduction of detailed forms where artists could indicate research interests, as well as keyword descriptions, for their work. As computerisation was introduced in the 1990s these details were transferred to a database and this continues to help navigate the many slide files. Artists were encouraged to produce the best quality slides they could afford and consider these files as a showcase of their work, attracting curators, picture researchers and fellow artists. Not everyone could afford the time or energy to produce professional images, but all slides were accepted and stored in archival hanging files along with artists' statements, press clippings, ephemera, photos and anything else the artist sent. The first $\mathrm{CD}$-ROMs received were artworks exploring digital interactivity rather than portfolios of images, but this soon became the preferred medium for cash-strapped artists. As artists increasingly incorporate an element of performance or film into their work, DVDs do more than replace videotape and are like multiples of work rather than a cheap form of documentation.

Although artists continue to send print and digital 
materials, the slide file has most effectively been replaced by the dedicated website. Interestingly the rise of the digital environment has changed the WAL/Make collection of slides and papers from being a professional presentation of women's artwork to providing a pool of raw material. Art practice has become self-reflective and has absorbed the habit of documentation, while critical theory steers researchers to consider artwork in different socio-political contexts. The artist's 'artist file' has become an intriguing proposition as a digitised object.

\section{To campaign is to teach? An image-conscious art history}

The slide will forever be associated with teaching art in the late-20th century, and the digital image continues to serve equally as teaching aid and visual evidence. Between the artist and the teacher of art often the same woman - there is a longstanding passion for introducing women's artwork into education. The slide was a powerful tool, already the focal point of support group meetings where the lights went off and women would 'speak out' through what they could say about their own work. Making art was an act of self-assertion; making slides brought work into the public domain and projecting them was empowering in the way that seeing your artwork online might be today.

This mutual support was vital since women were subject to hostility and indifference in educational settings. WAL/Make contributed to a television documentary Portrait of the artist as a young woman (1987) 1 that examined the difficulties experienced by women art students in the UK. Whether we needed to group together as women artists was arguable, but the need for role models was not. Art historian volunteers quickly came forward to track down museum and commercial slide sources and build up an educational slide collection. In 1994 the WAL produced a slide pack of 40 slides that sold out immediately to teachers and lecturers and was followed by an edited version of 24 slides. Like the WAL itself each selection juxtaposed contemporary artists with historical artists to create immediate visual as well as critical connections. $^{2}$

\section{Collecting evidence}

WAL/Make included artists who had no idea the library existed. A newsletter which became a journal and then a magazine ${ }^{3}$ was published to highlight women's art practice wherever it could be found, and a press cutting agency was enlisted to scan the full gamut of UK journalism, resulting in an extraordinary collection of press cuttings, organised into a vast index.

More artists' files were created from the ephemera, press photos and transparencies plucked from unsolicited post, fished out of the bins of disdainful editors, or rescued from desk clear-outs. The wonderful archive of over 400 photographs relating to the life and work of Dame Laura Knight is said to have been retrieved from a skip, but most of the archives relating to individual historical artists were secured from family members, as in the case of Lilian Holt and Jean Spencer (also represented in the library archives at Chelsea College of Art). The archive on the British Pop artist Pauline Boty was an exception, as WAL was approached to document this artists' oeuvre before it was dispersed for sale by the family, which resulted in an extensive photographic record of $35 \mathrm{~mm}$ and large-format transparencies.

Questionnaires were sent to private and public art collections in the UK to locate slides of women's art work for sale - and these were very scarce in the 1980s. By 1990 art historian volunteers had completed several major projects with institutions and artists' organisations to establish archives on, for example, women artists in the collection of the Imperial War Museum or the Women's International

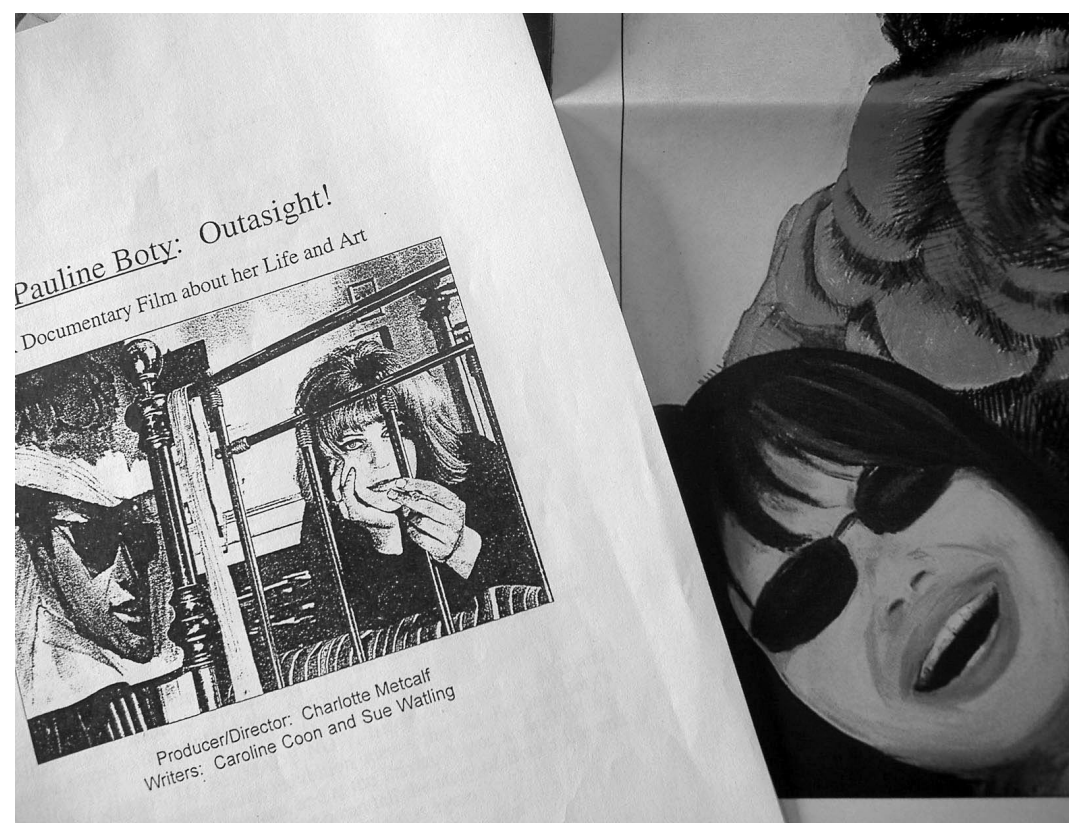

Papers from the Pauline Boty file. 
Art Club (1900-1976). The catalogue collection of the Society of Women Artists (1855 to the present day) was used to complete the collection held in the National Art Library at the Victoria \& Albert Museum (V\&A) in London, with the help of the President of the Society herself. WAL also worked with the original organisers of the International Festival of Women Artists of 1980 to put together an archive of texts, slides and ephemera which complements the original postcard archive of the same event held at the Library Resource Center at the National Museum of Women in the Arts.

A researcher recently worked her way through the set of published reviews belonging to the collection's oldest archive: the Women's International Art Club. From these she was able to identify fin de siècle concepts of internationalism provoked by the fact that these women artists deliberately defied national borders to exhibit together and declared themselves an international organisation. ${ }^{4}$ WAL/Make continued this tradition, forming an alliance with women's art groups throughout Europe (International Women Artists Association), and taking on collaborative projects. Breaching boundaries is as strengthening a tactic as collaboration, and the WAL/Make also bears witness to the woman artist's emergence from the studio/home as she vigorously launched visual arts practice into the wider community to make it connect with women's daily lives. From artists' residencies to the notion of cross-disciplinary collaboration and micro-interventions these strategies helped redefine the role of all contemporary artists working today.

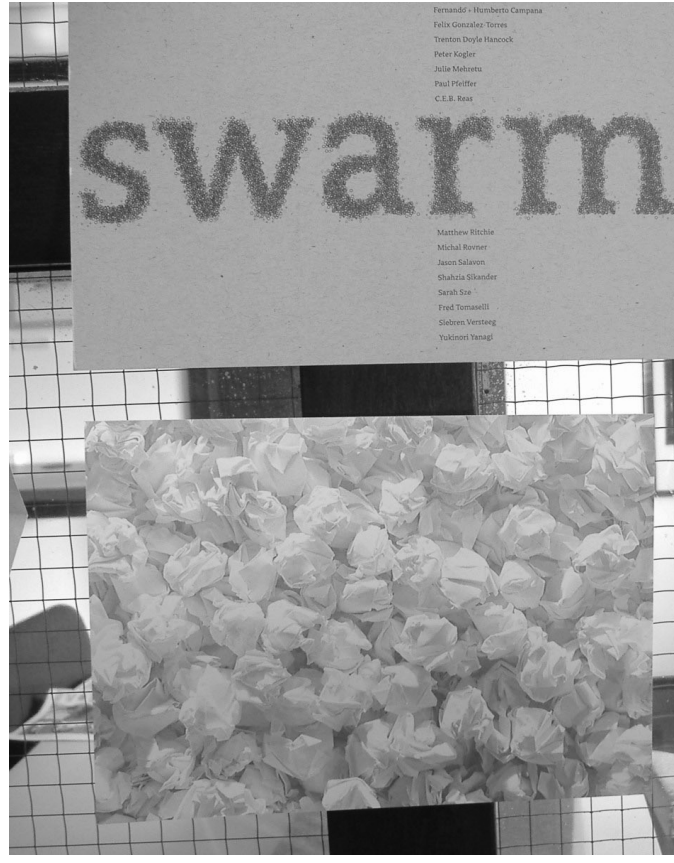

Special Collection office view.

\section{Spreading the word and the net}

WAL/Make outgrew the original name of the Women Artists Slide Library once the idea of tracking the success of unaffiliated artists and collecting material from galleries rather than artists became the norm. The printed collection expanded when the Nerwsletter became the Women Artists Slide Library Journal and began to review books. The library's symbiotic relationship with its publication continued as the journal developed into a high profile magazine. Supported by Arts Council funding from the mid-1980s until 2002, the publication addressed gender parity as an arts publication with a strong link to art education and enjoyed a high subscription take-up by libraries in art colleges around the world. The magazine's network of scholars, writers, curators, gallerists and artists guaranteed the library a fresh supply of ideas and images as new artists' files were constantly created. A particular intimacy was maintained with artists and their gallerists as a result of their eagerness to feature in the magazine. The library would routinely contact artists on behalf of researchers or direct them to their galleries.

But although the concept of education and scholarship is implicit in the very word 'library', artistic success is not. When publishing extended to books distributed by IB Tauris and consultancy became a driving force in the organisation, the Women's Art Library needed to drop the word library from its title. After much deliberation WAL became Make, the organisation for women in the arts in 2001. 'Make' persists as a nickname that associates the collection with its critical publishing past.'

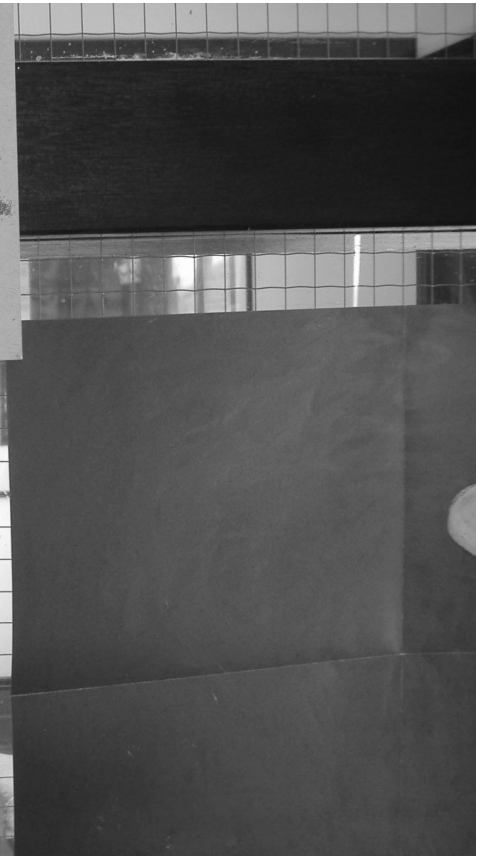

Photo: A. Greenan, 2006.

\section{Dutiful daughters}

The WAL/Make flourished with the help of several generations of women, all equally impassioned and committed to supporting women's artwork on feminist terms. And yet the generational differences were acutely felt within the organisation, where separate feminist cultures emerged and played out in the two activities of publishing a topical magazine and running an artists' membership. The very term 'feminist' swung from 
being the stamp of approval to the proverbial hot potato. As with all arts organisations, resources were limited and managing the successful growth of the library had to be set against the voracious metabolism of the magazine, which saw itself - like many women artists - pushing through the 'feminist' time barrier towards 'girl power' and whatever else lay in the future. The magazine, being a limited, editorial space, was not the showcase for those who deposited slides in the library.

From a women artists group seeking recognition for women's art, WAL/Make became locked into competing as a highoctane arts organisation. 'Debate' became the organisation's sales pitch, and the magazine assumed the position of catalyst, devil's advocate, expert and talent scout to operate within the art world and seduce its audience and funders in a way that the library could not. This did not last.

\section{A special collection is born}

Changes in UK public arts policy brought about the end of funding for the organisation in 2002. As the last Make magazine went out, the institutional archives were boxed up into $40+$ containers and it seemed that this was the end of 20 years of women's art advocacy. But was it?

The funders worked with WAL/Make's management to produce an exit strategy that concentrated on keeping the library collection intact, along with the archive, and securing its future as an ongoing project. The Library at Goldsmiths was selected to receive the WAL/Make archive and resource into its Special Collections in 2003. WAL/Make has grown into a collection of national and international significance with roughly 3000 books and exhibition catalogues, 10,000 files on individual artists, and 20 feet of archives, in addition to the 400 files in the Women of colour index.

Throughout its development from an activist project to an arts organization, the remit to promote the appreciation of the work of women artists endured and is now written into the deed that gifted the collection to Goldsmiths. The opportunities for promoting images through a special collection in the 21 st century are worlds apart from what they were for a slide library in the 1980s. Digitisation of these unique images caught on slide offers an enhanced visibility that the early artist slide donors could never have dreamed of.

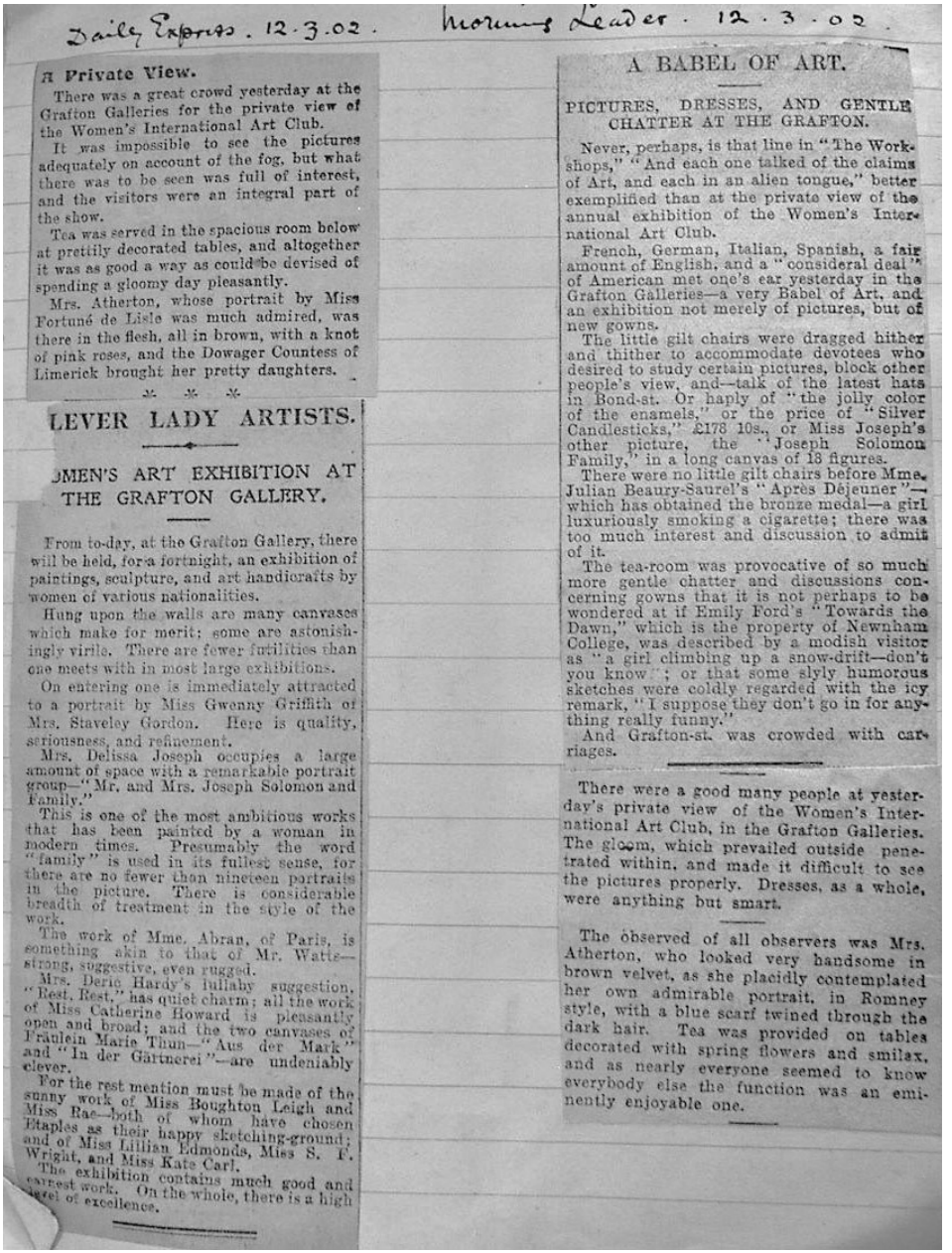

Item from the Women's International Artists Club archive, 1902.

Photo: A. Greenan, 2006.

\section{The picture imperative}

Feminist pride notwithstanding, the woman artist is an artist like any other, prone to destroying work and dispensing with the borderline results of experiment or collaboration. In direct contrast, the slide library's accumulation of images is the subject of preservation efforts and in many cases more secure than the artworks it represents. The only comparable collection is that at the Library Research Center of the National Museum of Women in the Arts (Washington DC), with whom there is little overlap except for key publications. Thanks to ARLIS/UK \& Ireland and its Design and applied arts index travel award, I made a research trip to the US and was delighted to find that our collections neatly dovetail to demonstrate the rich extent of art produced by women. The Library Resource Center at the NMWA has a team dedicated to developing a database that combines text, images and media, Clara, which should go live by 2007 and be an exciting online resource on women artists. ${ }^{6}$

The image collections of WAL/Make $(125,000$ slides, 500 posters, 1500 photographs) remain 
unique and largely unpublished. Goldsmiths' Library is developing plans for digitisation and cataloguing using CALM. The printed items are being catalogued and their growing presence in the OPAC has resulted in a doubling of the number of visitors since the collection was transferred to Goldsmiths.

A new website was set up in $2005^{7}$ and has an average of 3600 visits (20,000 hits) per month. Approximately 25\% come from outside the UK and these visitors spend longer than average on the site. $25 \%$ of users view the 'magazine back issues' section where a link to the full-text e-journal is made available via our partners, $\mathrm{H}$. W. Wilson.

Researchers also find the resource through our participation in the portals Genesis, AIM25 and, it is hoped, WAAND, which is the brilliant new portal based at Rutgers University. ${ }^{8}$

Visitor statistics show that the collection continues to serve researchers in a wide range of subjects, working across all educational and professional levels. $80 \%$ of these were from Goldsmiths, drawn equally from social science and arts and humanities departments. Most of our users are researching contemporary artists, about half as many have historical questions. They use the collection for PhD and dissertation work, research for art projects and publication research.

What the statistics don't tell is how guiding these researchers through the WAL/Make collection is like a game of mirrors: artist and researcher are more often than not driven by the same issues, eager to catch an authenticating likeness in someone else's work. Since many of the researchers are also artists, or were artists at some time, this should come as no surprise, but within this play between reflection, ideas and images there is a much wider domain to explore. Most artwork acknowledges and aims to be accessible to a non-art audience, but can we assume this holds true for their images? For instance is the answer to enhancing accessibility to artwork as simple as signing up to a space on Flickr?"

A recent project carried out for the internal launch of the WAL/Make in Goldsmiths in May 2006 invited key individuals representing academic departments throughout the College to choose ten images from the collection that might reflect aspects of their personal research. Making these choices and co-ordinating the final slide show revealed just how far an image search can take you into the realm of women's art practice and initiate a kind of selfdiscovery, regardless of critical art experience. The project highlighted the big difference between searching images and picture research. No image was considered in isolation but each was seen as part of an oeuvre, an idea, and similarly the overall resource acted as a framework for viewing. The image thus gained autonomy, and could shift a selector's perspective as easily as illustrating it.

When the Women's Art Library first began it was the books and gathering scholarship that gave the artists' slide files a much needed context. Now each unique artist's slide is endowed with all the heightened expectations that technology can bestow, as more and more image collections worldwide are integrated through digital development. This digital future draws the development of the Women's Art Library back to its origins, and it will be these women artists' files that give the publications and future scholarship an exciting new context.

\section{References}

1. The film was broadcast in 1987 by Central Television and was instigated by the artists Pam Skelton and Anne Lydiat; it featured interviews with leading feminist art academic Griselda Pollock and with Pauline Barrie, whose early involvement with the Women Artists Slide Library established it as an indispensable arts organisation with a political agenda.

2. The Women's Art Slide Pack included information sheets on individual artists, and included topic headings to facilitate its use by teachers. Artists included in the original selection were Margaret Benyon, Zarina Bhimji, Sutapa Biswas, Barbara Bodichon, Louise Bourgeois, Sonia Boyce, Miriam Cahn, Constance Marie Charpentier, Eileen Cooper, Audrey Flack, Elisabeth Frink, Artemisia Gentileschi, Fay Godwin, Leslie Hakim-Dowek, Margaret Harrison, Hannah Höch, Tess Jaray, Angelica Kauffmann, Mary Kelly, Käthe Kollwitz, Barbara Kruger, Loraine Leeson, Judith Leyster, Ana Mendieta, Annette Messager, Jacqueline Morreau, Ana Maria Pacheco, Deanna Petherbridge, Adrian Piper, Paula Rego, Faith Ringgold, Rachel Ruysch, Miriam Schapiro, Jo Spence, Nancy Spero, Mierle Laderman Ukeles, Suzanne Valadon, Barbara Vijayakumar, Kate Walker and of course Frida Kahlo.

3. First published in 1983 as a newsletter for the Women Artists Slide Library, the publication was developed throughout the 1980s and early 1990s as the Women Artists Slide Library journal and then as Women's art magazine. See http://make.gold.ac.uk/magazine.php

4. Grace Brockington, 'Women's art clubs and their 
internationalist aspirations at the fin de siècle', paper delivered at the conference Internationalism and the arts: Anglo-European cultural exchange at the fin de siècle, 3 July 2006.

5. The Women's Art Library still has two books in print which are distributed through IB Tauris (http://www.ibtauris.com). They are Fran Lloyd, Contemporary Arab women's art - dialogues of the present (London: The Women's Art Library, 1999), and Angela Dimitrakaki, Pam Skelton and Mare Tralla, Private views: spaces and gender in contemporary art from Britain and Estonia (London: The Women's Art Library, 2000).

6. National Museum of Women in the Arts, http://www.nmwa.org/.

7. http://www.make.gold.ac.uk/.

8. See http://waand.rutgers.edu/ and Ferris Olin's article in this issue of the Art libraries journal.

9. 'Democratising the image: creating a global learning community', CHArt Round-table Discussion held on 10 November 2005 at the Institute for Contemporary Arts, London. This point was made in relation to the idea that the users of images are shaping Creative Commons resources like Flickr (http://www.flickr.com), where individuals put their own images on the web and manage their access with personal tags.

10. The slide show: a pleasurable encounter with the collection, http://make.gold.ac.uk/pdfs/Softslides.pdf.

\author{
Althea Greenan \\ Women's Art Library/Make \\ Senior Library Assistant, -Special Collections \\ Goldsmiths, University of London \\ Lewisham Way \\ London SE14 6NW \\ UK \\ Email:a.greenan@gold.ac.uk
}

